Fire and Invasive Plants Special Feature

\title{
Economic and Social Impacts of Wildfires and Invasive Plants in American Deserts: Lessons From the Great Basin
}

\author{
Mark W. Brunson ${ }^{1}$ and John Tanaka ${ }^{2}$ \\ Authors are ${ }^{1}$ Professor and Head of Environment and Society Department, Utah State University, Logan, UT 84322-5215, USA; and ${ }^{2}$ Professor and \\ Head of Renewable Resources Department, University of Wyoming, Laramie, WY 82071-3354, USA.
}

\begin{abstract}
Research on the impacts of wildfire and invasive plants in rangelands has focused on biophysical rather than human dimensions of these environmental processes. We offer a synthetic perspective on economic and social aspects of wildfire and invasive plants in American deserts, focusing on the Great Basin because greater research attention has been given to the effects of cheatgrass expansion than to other desert wildfire/invasion cycles. We focus first on impacts at the level of the individual decision-maker, then on impacts experienced at the human community or larger socio-political scales. Economic impacts of wildfire differ from those of invasive grasses because although fire typically reduces forage availability and thus ranch profit opportunities, invasive grasses can also be used as a forage source and ranchers have adapted their grazing systems to take advantage of that circumstance. To reduce the threat of increased ranch bankruptcies, strategies are needed that can increase access to alternative early-season forage sources and/or promote diversification of ranch income streams by capturing value from ranch ecosystem services other than forage. The growth of low-density, exurban subdivisions in Western deserts influences not only the pattern and frequency of wildfire and plant invasions but also affects prevailing public opinion toward potential management options, and thereby the capacity of land management agencies to use those options. Outreach efforts can influence public opinion, but must be rooted in new knowledge about multiple impacts of invasion and increased wildfire in American deserts.
\end{abstract}

\section{Resumen}

La investigación se ha centrado en el impacto biofísico del los incendios naturales y las plantas invasoras en los pastizales, en lugar de la dimensión humana en esos procesos medioambientales. Ofrecemos una perspectiva sintética sobre aspectos económicos y sociales de los incendios naturales y las plantas invasoras en los desiertos de América, enfocándonos a la región de la Grean Basin debido a la importancia de las investigaciones sobre el efecto de la expansión del zacate cheatgrass que a otros incendios/ciclos de invasión en los otros desiertos. Nos enfocamos primero, en los impactos a nivel individual de toma de decisiones después, en los impactos experimentados a nivel comunidades humanas o escalas socio-políticas mayores. El impacto económico de los incendios naturales difiere de aquel provocado por la invasión de pastos porque, mientras el fuego reduce la disponibilidad de forraje y la oportunidad de un ingreso en el rancho, pastos invasores también pueden ser usados como fuente de forraje y los rancheros han adaptado sus sistemas de pastoreo para sacar ventaja de esta circunstancia. Para reducir el riesgo de bancarrota en el rancho, se requieren estrategias que incrementen el acceso a fuentes de alternativas de forraje al principio de la temporada y/o promover la diversificación del ingreso del rancho valorando los servicios medioambientales de éste, en lugar de solo el forraje. El crecimiento de subdivisiones ex-urbanas de baja densidad en los desiertos del Oeste, influencian no solo el patrón y frecuencia de incendios naturales e invasión de plantas sino también, afectan la opinión pública actual hacia opciones potencial de manejo y como consecuencia la capacidad de las agencias que manejan las tierras de aplicar esas opiniones. Los esfuerzos para influenciar la opinión pública tienen que estar basados en conocimiento nuevo a cerca del impacto múltiple de las invasiones y aumento de incendios naturales en los desierto de América.

Key Words: cheatgrass, forage availability, fuels reduction, public attitudes, ranching

\section{INTRODUCTION}

Nonnative plant invasions and changes in wildfire cycles are important ecological concerns in the desert regions of the western United States, but they are equally important economic and social concerns (Chambers et al. 2009; Epanchin-Niell

\footnotetext{
Research was supported by the Utah Agricultural Experiment Station, Utah State University, Logan, UT, USA, and by the Eastern Oregon Agricultural Research Center. Approved as UAES journal paper 8126 .

Correspondence: Mark Brunson, Environment and Society Dept, Utah State University, Logan, UT 84322-5215, USA. Email: Mark.Brunson@usu.edu

Manuscript received 18 February 2010; manuscript accepted 13 October 2010.
}

et al. 2010). It has become almost a cliché that natural resource management problems are "people problems." Even so, the literature on biophysical aspects of wildfire and invasive plants is considerably more extensive than the literature on economic or social aspects. Moreover, existing studies tend to focus on regions other than Western deserts; for example, a recent bibliography of social science publications on wildland fire and fuels management (Shindler et al. 2008) yielded 168 published articles and federal research station reports, barely a dozen of which focused on rangeland or desert regions or associated human communities.

In this paper we present a synthetic perspective on economic and social aspects of wildfire and invasive plants in American 
deserts, focusing primarily on cold deserts because concern about the cheatgrass/wildfire cycle in that region has generated most of the available research. We have found no peerreviewed literature on similar species in hot deserts although a buffelgrass working group in southern Arizona has widely distributed information about economic and social implications of that invasion (Southern Arizona Buffelgrass Coordination Center 2007). We have organized our discussion into two sections according to the scale at which impacts occur, focusing first on economic impacts and then social impacts at each scale. The first section focuses on the level of the individual decisionmaker. For economic impacts, this level of research addresses activities and decision processes of the ranch or land manager, whereas for social impacts it can apply to any individual whose perceptions or behaviors may be affected by wildfire or invasive plants. We then proceed to impacts experienced by communities or larger social-political scales (county, state, region, etc.). It is important to note, however, that interactions and feedbacks also occur across scales, between social and economic spheres, and between wildfires and invasive plants. For example, a manager's decision whether to try to control invasive plants may be affected by perceptions of the impact of weeds at the larger landscape or watershed scale, since the cost-benefit calculation is affected by the likelihood of reinfestation from neighboring properties (Aslan et al. 2009). Likewise, economic decisions can be influenced by noneconomic social factors, such as if a land manager considers costs associated with engaging in an activity that members of a nearby community largely oppose.

\section{IMPACTS AT THE DECISION-MAKER LEVEL}

\section{Ranch-Level Economic Decisions}

Wildfires and invasive plants can have different economic impacts depending on the timing of the impact and the intended use of the resource. In this section we first examine the impacts of cheatgrass (Bromus tectorum L.) on ranching operations, then discuss how different interest groups might view the species and similarities and differences in the hot deserts of the Southwest. Because cheatgrass dominance changes the fire ecology of a site, we look at how this change in fire regimes affects a typical ranching operation and what may be some of the options for ameliorating those effects. Although the focus is on cheatgrass in the Great Basin, the principles described could be applied to other invasive plants in cold or hot deserts that have the potential to change wildfire regimes. To date, no such studies have been conducted and published.

To understand economic effects of cheatgrass on ranches it is important first to consider how a typical ranch in the region operates. Great Basin ranches typically use a variety of forage sources to meet seasonal nutritional needs, as seen in the annual forage cycle depicted in Figure 1. In some seasons there may be few options or alternative sources. Many ranches operate on both private and public lands, with the season of use on public lands prescribed by the land management agency.

Season of use and the flexibility of such use are significant factors influencing grazing on rangelands affected by both invasive annual grasses and wildfires. In spring, perennial grasses begin to grow while cheatgrass is highly productive. In

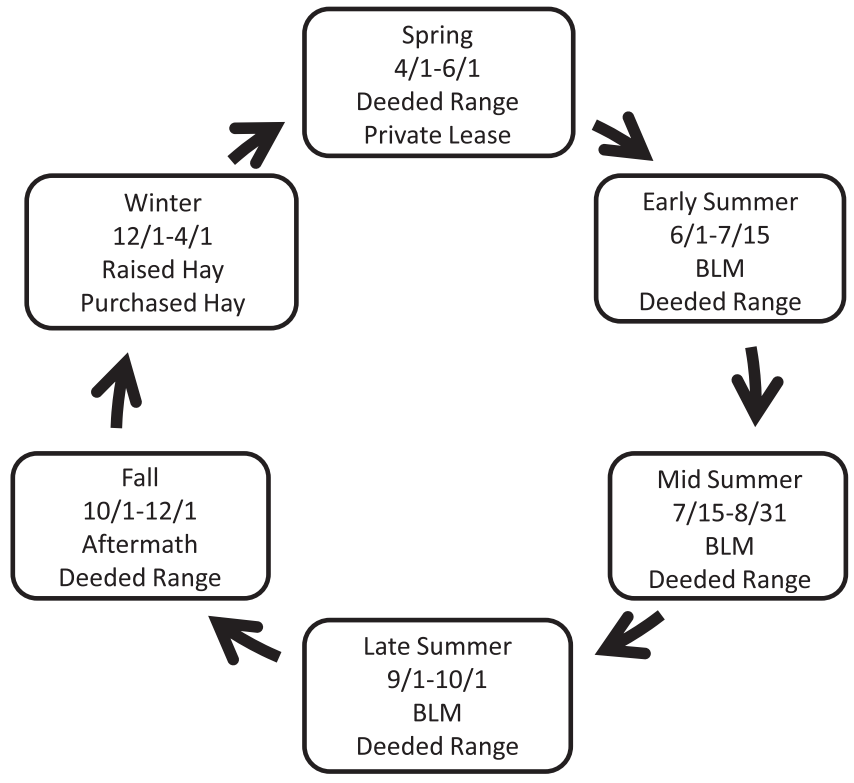

Figure 1. Yearlong feed and forage sources for a typical Great Basin ranch in Oregon showing where cattle will be at different times of the year. Location and dates affect decision-maker management options.

early summer, cheatgrass begins to senesce while the perennial grasses are growing well. By midsummer, cheatgrass has turned brown and has little forage value while the perennials are just going to seed and beginning to senesce. Sometime between early to midsummer, cattle may be moved onto public land allotments where they will stay until they return to private lands in late summer or early fall. By late summer the perennials have dried out, but still maintain some nutritional value. Most cattle are pastured on private lands with greener forage during autumn. Through the winter cattle are generally fed hay on private lands.

Although outside factors such as the rancher's objectives, cattle prices and input costs, and climate affect the general size of the operation, it is the within-year variation in forage type and availability that determines the number of animals that can be kept on the ranch. Weather plays an obvious role in annual variability, but changes in vegetation composition also can affect the amount of relative forage in each season (Aldrich et al. 2005; Satyal 2006; Maher 2007). Wildfire can cause significant forage loss during critical times of the year. This may be exacerbated on public lands when grazing may be prohibited for $2 \mathrm{yr}$ postfire (Maher 2007).

Much of the historical work on ranch economics and the impacts from management changes has only looked at singleyear models, or assumed that each year was independent of all other years. In recent years, economists have begun building recursive ranch models in which what happens in year 1 affects the outcomes in year 2 and so on. The basic outcome of these types of models is that it is possible to closely model how a ranch (i.e., the decision-maker) would respond to changes if they behaved as profit maximizers. If the herd has to be reduced due to drought or wildfire, it will likely take several years to rebuild the herd based on retaining more replacement heifers each year. All of the models being referenced assume that the rancher behaves as if profit maximization was the only goal. In 


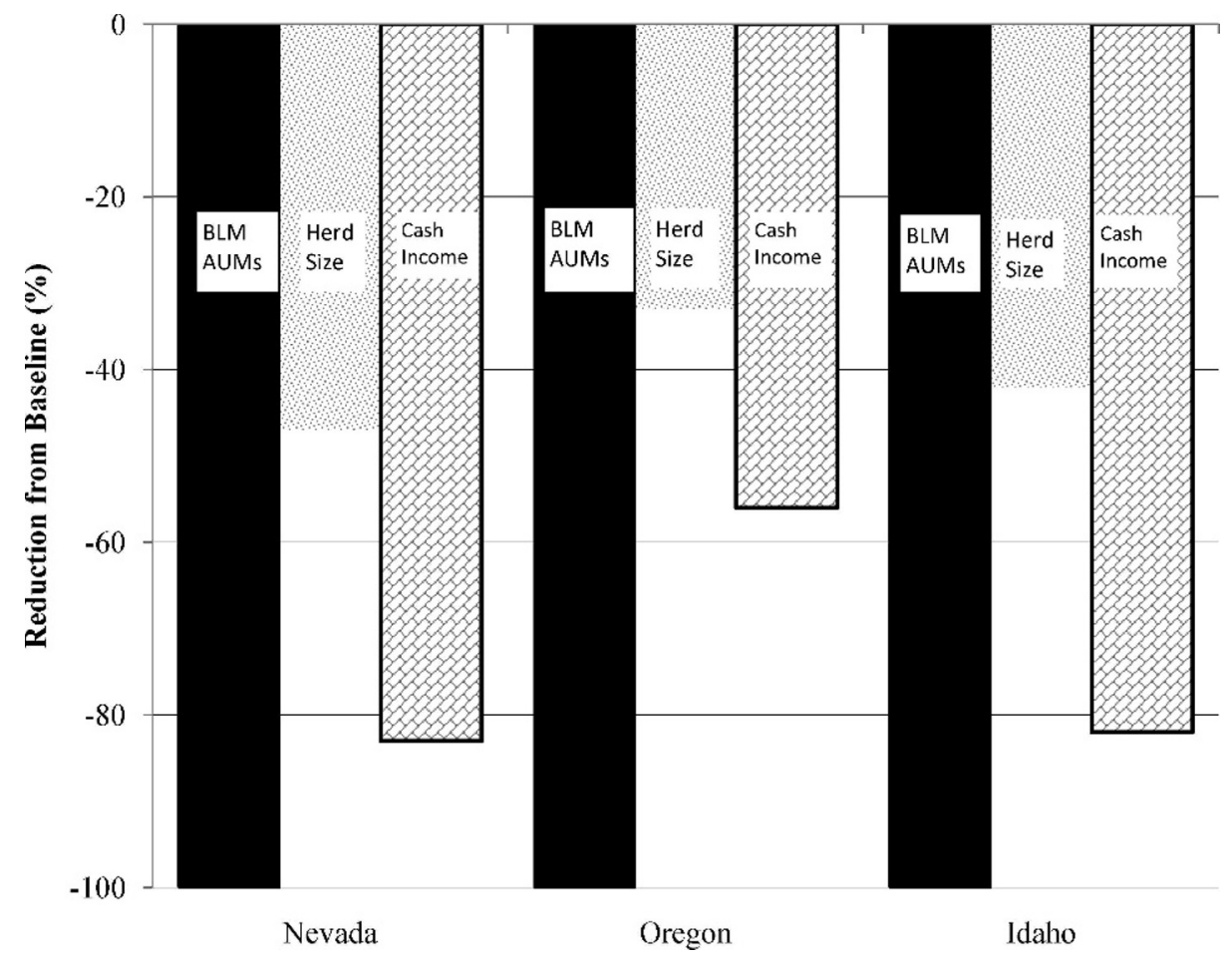

Figure 2. Percentage of reduction in cattle herd size and net cash ranch income from a $100 \%$ loss of Bureau of Land Management grazing for typical ranches in Nevada, Oregon, and Idaho (Torell et al. 2002).

reality, however, ranchers have a multitude of goals that may alter their actual decisions (Torell et al. 2001).

\section{Cheatgrass and Ranching}

Cheatgrass plays an interesting dichotomous role when it comes to ranching. At certain times of the year, it may provide the vast majority of forage for cattle. It also competes with native perennial grasses for scarce resources such as water and nutrients, with the resulting changes in forage availability later in the year. While many ranches have adapted to this change in seasonal forage availability, it does leave them somewhat vulnerable when cheatgrass is not available. Efforts are ongoing to make values beyond forage values, such as wildlife habitat and reduced soil erosion, part of the decision process to assess their impact on final outcomes (Aldrich et al. 2005).

So how will a ranch respond to these changing situations and other resource values? In studying the effects of reduced grazing on Bureau of Land Management (BLM) allotments to improve sage grouse habitat, a ranch model was developed that would allow us to evaluate the economic impacts on the ranch (Torell et al. 2002). Although it did not address cheatgrass specifically, it does show the effects of losing use of the BLM allotment (Fig. 2) for whatever reason. As shown in Figure 2, losing $100 \%$ of the BLM allotment resulted in different levels of impacts for the three states studied. The differences were due to the options assumed to be available for the ranchers in that particular region.

\section{Wildfires and Ranching}

Because cheatgrass tends to change the fire return interval in sagebrush-dominated rangelands in the Great Basin, Maher (2007) examined how random fire events change the profitability of the ranch. The basic assumptions were that fires were more likely with cheatgrass present than without, the fire return interval was shortened (i.e., fire was more likely to occur), and grazing must be removed from the entire allotment following a fire. In this case we assumed the fire would occur late enough in the season that it would not affect grazing in the year of the fire, but that the following $2 \mathrm{yr}$ would result in no forage available from the public allotment.

The most profitable solution if the wildfire occurred in year 17 chosen by the model is shown in Figure 3 as a representative result from 100 random fire events (one or two over a 40-yr planning horizon). This solution is highly unrealistic as it suggests that a rancher should begin to reduce herd size some years prior to the fire-which in turn suggests a level of clairvoyance about future wildfires that has never been observed in field studies-to reduce the economic shock associated with sudden forage loss. What is significant is that even under this impossibly favorable scenario, brood cow stocking must be cut nearly in half in order to cope with the loss of forage. The resulting cost to the producer depends on the price cattle are bringing in the market at the time herd size must be reduced.

As indicated by these results, prediction of economic impacts from wildfires and invasive plants on ranching enterprises in the Great Basin is not clear-cut. The oft-chided economist's response of "it depends" rings true; it really does depend on what assumptions are made, what the goals of the rancher are, and what the goals of the landowners are. These things are not always compatible. At a minimum, a rancher requires some place with forage or feed to put his or her cattle herd every day of the year. As changes are made in the availability of forage sources, the ranch must adjust where those cattle are and what they are going to be fed. Generally speaking, ranchers adjust to 


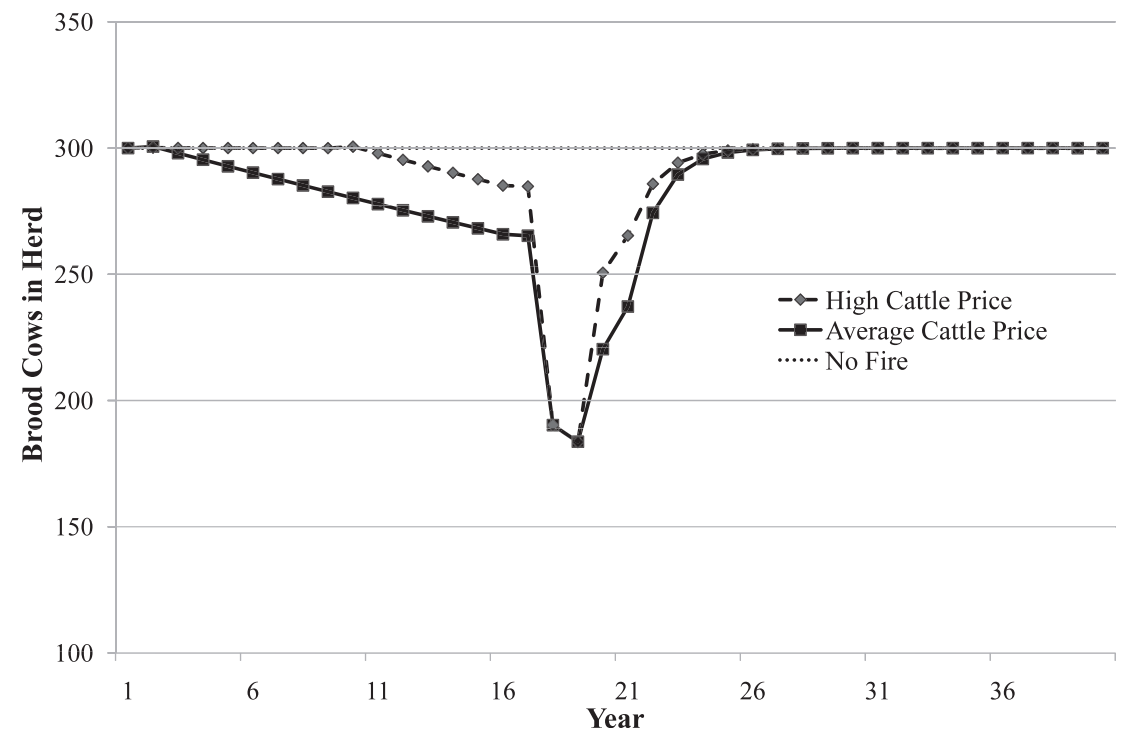

Figure 3. Example of effects on herd size from a wildfire in year 17 followed by $2 \mathrm{yr}$ of nonuse (Maher 2007). Cattle prices affect both the profitmaximizing herd size and the economic impact on the ranch compared to a no-fire scenario. Average cattle prices (calve $=\$ 94.50$ per hundredweight $\left[\mathrm{cwt}^{-1}\right.$ ] in 2005) calculated over a 20 -yr period. High cattle prices (calves $=\$ 112.63 \mathrm{cwt}^{-1}$ ) set at 1 standard deviation above the average. Low cattle prices resulted in the ranch having a $100 \%$ chance of going bankrupt.

the least costly way of raising the animal. As such, most alternatives they are faced with are higher-cost or costprohibitive if they are to stay in business.

Wildfires are likely to be most devastating to a ranching operation with few alternative forage sources. If the wildfire was confined to a single ranching operation, there may be more opportunity for local private land leasing to be available. However, as wildfires become more widespread, and the overall forage base grows smaller even as more producers compete for alternate sources, private land leases would become less available and likely more costly. With increasing fire frequency, the likelihood of the ranch going out of business increases. If average cattle prices are realized over the life of the ranch, the probability of the ranch going bankrupt increases to $32 \%$. If prices are high (1 standard deviation over the long-term average), the chance of going bankrupt is $11 \%$. With low prices ( 1 standard deviation below the long-term average), the chance is $100 \%$.

\section{Psychological and Behavioral Impacts}

At the individual level, social impacts of wildfires or invasive plants are expressed as changes in attitudes, beliefs, and behaviors. These can result from direct exposure to environmental changes or events, or they can result from indirect exposure (e.g., via personal contacts or news media) that causes people to reevaluate their ideas or actions. For wildfire, psychological or behavioral effects can result if an individual suffers direct damage to property or health, but they also can result from exposure to smoke, changes in scenic quality of important viewsheds, direct effects experienced by friends or relatives, or memorable images of impacts reported by news media. Often land managers and other range professionals are most interested in how their educational activities, as well as events that may or may not be beyond an agency's control, have affected citizens' responses to wildfire, fuels reduction, or invasive plant management. Such responses may include behavioral changes-e.g., increasing efforts to reduce fuel hazard on one's own property, or supporting efforts to block a prescribed burning proposal-or psychological changes such as an increase in trust or willingness to listen.

The intensity and direction of these psychological and behavioral impacts is likely to vary depending upon a number of personal and contextual factors, including the individual's assessment of catastrophic risk, attributions of blame for undesirable events, degree of day-to-day interaction with wildlands, and beliefs about society's right to manipulate natural environments and the nonhuman organisms found there. Brunson and Evans (2005) studied how acceptability judgments regarding prescribed fire as a fuels treatment were affected by a 2003 incident in which a prescribed burn in northern Utah escaped, due to what a subsequent review found to be poor planning and implementation by the Forest Service. The resulting wildfire burned more than 3000 ha and engulfed the Salt Lake and Utah valleys in smoke for a week. The authors had access to baseline acceptability data from a previous acceptability study in the same area (Brunson and Shindler 2004), and so could resurvey residents of affected urban areas as well as conduct a new survey of citizens living in the more rural county where the fire burned.

Brunson and Evans (2005) expected that acceptability of prescribed burning would decrease, and were surprised to discover no significant difference in acceptability: in both 2001 and 2003 , more than $80 \%$ of respondents believed there is a place for prescribed fire in the fuels-reduction toolkit, while the percentage of people who preferred it not be used due to negative impacts rose only from $2 \%$ to $9 \%$ of all respondents. However, they also found a significant reduction in the confidence respondents expressed regarding state and federal agencies' ability to use prescribed fire properly, from nearly $80 \%$ to less than $60 \%$. A more recent survey in selected Great Basin locations (Shindler et al. 2011) found that the gap between acceptability of fuels management and confidence in agencies' ability to use the practices exists even in the absence 
Table 1. Percentage of small-acreage rangeland owners (1-20 ha) in two montane and two desert areas in Utah who reported taking action to reduce wildlife hazards on their properties.

\begin{tabular}{lcccc}
\hline & Mountain1 & Mountain2 & Desert1 & Desert2 \\
\hline Made home less flammable & 25 & 29 & 11 & 16 \\
Conducted a controlled burn & 31 & 20 & 17 & 14 \\
Removed flammable vegetation & 46 & 46 & 61 & 43 \\
No action & 20 & 25 & 25 & 35 \\
\hline
\end{tabular}

of events such as a botched fuels treatment, with the percentage of respondents expressing "full" or "moderate" trust in BLM and Forest Service ability to implement fuels treatments lagging $15-25 \%$ behind acceptability of herbicide application and mechanical treatment as well as prescribed burning.

Another contextual influence on acceptability is the nature and frequency of individuals' interactions with natural resources and their management. Rural and urban residents differ in terms of the likelihood that they will incur direct impacts from wildfire, and also in the type of potential impact (e.g., loss of livelihood vs. loss of amenity value). Shindler et al. (2011) compared rural and urban residents' acceptability judgments about a series of fuels management options that included prescribed fire, mowing of sagebrush, felling of pinyon and juniper, chaining, and herbicide application. They found that while both rural and urban publics agreed that prescribed fire is the most acceptable approach, a majority of rural citizens judged the other four practices as acceptable while less than $50 \%$ of urban respondents rated herbicides and chaining as acceptable. These differences in acceptance levels may be linked to beliefs about the threats that confront desert rangelands. Shindler et al. (2011) found that with the exception of wildfire and invasive plants, which were equally likely to be perceived as threats by urban and rural residents, urban respondents otherwise tended to see human activities (e.g., subdivision development, off-highway vehicle use) as threats to Great Basin rangelands while rural residents had higher levels of concern about environmental processes such as overly dense sagebrush or juniper encroachment.

Data on the contexts that affect behavioral responses to wildfire are less readily available than those on psychological responses. A 2008 survey of beliefs and behaviors of people who own small-tract rangeland properties (0.8-20 ha) in Utah asked whether respondents had taken several actions to reduce wildfire hazards on their properties (Table 1; M. Brunson and E. Kalnicky, unpublished data, 2008). In general, residents of the two montane study areas (Morgan County and central Summit County) were more likely to take preventive actions than those living in the desert study areas (western Utah County and northern Washington County). However, respondents living in the Great Basin setting, in the western part of Utah County, were more likely to have removed flammable vegetation from around their homes.

Less research has been conducted on psychological or behavioral responses to invasive plants, particularly the invasive Bromus and Pennisetum grasses that are of special concern in hot desert rangelands. However, Tidwell (2005) surveyed residents of 11 counties in Arizona, New Mexico, southern Utah, and southwestern Colorado about the acceptability of control options for invasive rangeland forbs such as yellow starthistle (Centaurea solstitialis L.) or spotted knapweed (Centaurea stoebe L.). He found evidence suggesting that the likelihood of direct impact was associated with acceptability judgments, as was the use of the land where control actions were being proposed (Table 2). In comparing acceptability judgments between use on multiple-use lands, parks and refuges, or areas adjacent to homes, there was no difference in the percentage of people who expressed high levels of acceptance for chemical, biological, or mechanical control, but the number of people who said chemical treatment is unacceptable was smaller for multiple-use lands than for protected areas or areas next to homes $(P<0.05)$.

The same study measured likely behavioral responses with a series of questions about the willingness of respondents to volunteer to participate in weed management activities, including control activities, monitoring, education, and restoration (Tidwell and Brunson 2008). Ten percent of respondents had engaged in volunteer activities-for example, as members of the Tucson-based Sonoran Desert Weed Whackers, which provides a volunteer work force for mechanical control of buffelgrass (Pennisetum ciliare [L.] Link) but also participates in education and restoration activities - and nearly half expressed willingness to participate (Table 3 ). Respondents who displayed higher knowledge about weed impacts were more likely to express willingness to volunteer, especially for control activities such as hand-pulling weeds.

\section{COMMUNITY-LEVEL AND LARGER-SCALE IMPACTS}

\section{Economic Impacts}

When studying the economic implications of wildfires and invasive plants in arid and semiarid regions, the impacts on individual ranches are just one part of the picture. Although ranching is a large economic part of many rural counties, it is not the only activity that will be affected by wildfires. Studies around the country have tried to quantify the economic impact on a county or region from wildfires, although most have focused on large forest fires (Morton et al. 2003). The purpose here is not to summarize all of those studies or to try to come up with a total estimate. Rather, we look at one such study to examine the types of impacts that might be evaluated. In a study of five counties in northern Nevada, Riggs et al. (2001) estimated the economic impacts associated with wildfires that covered 648000 ha. Costs for this region were categorized as lost animal-unit months of forage, cost for fence maintenance and infrastructure, firefighting costs, structure losses, livestock 
Table 2. Percentage of respondents in 11 Southwest counties who rated invasive plant control options as acceptable under varying land management or location contexts (adapted from Tidwell 2005).

\begin{tabular}{|c|c|c|c|c|}
\hline Control option available & Not at all acceptable & Slightly acceptable & Moderately acceptable & Highly acceptable \\
\hline \multicolumn{5}{|c|}{ National parks and wildlife refuges } \\
\hline Mechanical controls & 6 & 15 & 26 & 53 \\
\hline Biological controls & 10 & 17 & 29 & 44 \\
\hline Mechanical controls & 5 & 12 & 27 & 56 \\
\hline Biological controls & 9 & 17 & 31 & 43 \\
\hline \multicolumn{5}{|l|}{ Agricultural lands } \\
\hline Chemical control & 27 & 32 & 24 & 17 \\
\hline Chemical control & 30 & 33 & 26 & 11 \\
\hline Mechanical controls & 2 & 6 & 28 & 64 \\
\hline Biological controls & 12 & 18 & 31 & 39 \\
\hline
\end{tabular}

losses, and rehabilitation costs. In addition, they could recognize but not value losses of wildlife and recreation, erosion increases, maintenance of roads, decreased ecological states of the landscape, and loss of human life. The quantifiable part of the loss was estimated at over $\$ 13$ million.

Research on community- or larger-scale economic impacts of invasive weeds likewise is fairly common, but is are difficult to summarize due to variability in economic assumptions, data sources, modeling techniques, and whether studies focused on invasive species generally (e.g., Pimentel et al. 2000, 2005) or on particular species (e.g., Hirsch and Leitch 1996). A review by Duncan et al. (2004) reported that economic impacts of most rangeland and wildland invasive plants are poorly

Table 3. Percentage of survey respondents reporting participation, or willingness to participate, in volunteer activities $(n=571$; Tidwell and Brunson 2008).

\begin{tabular}{lc}
\hline & Yes \\
\hline $\begin{array}{l}\text { Do you participate in any type of volunteer work in your } \\
\text { community }\end{array}$ & $\%$ \\
Have you ever done any volunteer work associated with the & \\
$\quad$ environment? & 38 \\
Have you ever done any volunteer work with invasive plants? & 10 \\
Would you be willing to participate in volunteer invasive plant & \\
$\quad$ management? & 43 \\
Activity ( $n=245):$ & \\
$\quad$ Control & 57 \\
Monitoring & 55 \\
Education & 39 \\
Restoration & 38 \\
\hline
\end{tabular}

documented. Although comprehensive economic analyses exist at a state or regional basis for leafy spurge (Euphorbia esula L.), saltcedar (Tamarix spp.), and some knapweeds (Hirsch and Leitch 1996; Bangsund et al. 1999; Zavaleta 2000), other species have not been studied. Agricultural costs, including loss of grazing value, have been quantified for some species, but environmental and societal costs are typically not included in the analyses. The few analyses identified by Duncan et al. (2004) are primarily for woody or forb species. Surprisingly few if any economic impact analyses exist, although it's not uncommon to see predictions of community- or larger-scale impacts due to buffelgrass or cheatgrass (e.g., Fenner 2008; Rogstad 2008). Likewise, although economic impacts to outdoor recreation are certain to exist, very little has been done to quantify those impacts at watershed, state, or regional scales. Eiswerth et al. (2005) offered a method for estimating the ranges in which such impacts are likely to lie, and using Nevada as a case study calculated that even under conservative assumptions, the adverse influence of invasive plants on wildlife-related recreation alone were likely to range from \$6 million to \$12 million annually statewide.

\section{Social Impacts}

Research on social impacts of wildfire at the community scale draws heavily from the field of social science known as natural hazards research. Kumagai et al. (2004) reviewed the natural hazards literature and summarized lessons for how communities cope with a significant wildfire at the urban interface. The following findings are among those they report:

- Natural hazards don't always hurt economies, especially during and immediately following a wildfire, due to increased spending by firefighters and subsequent government funding. 
- People who live in hazardous areas tend to be overoptimistic about risk, i.e., they underestimate the likelihood of a catastrophic event and/or overestimate their ability to go through the event relatively unscathed.

- Providing information alone does not increase risk awareness or emergency preparedness-people need tangible evidence that they will be personally affected, and evidence of what the impacts are likely to be.

- Disasters often spark "blaming behaviors" against government institutions (see previous discussion of the escaped prescribed fire in Utah).

- Natural disasters have different impacts from technological disasters. Wildfires appear to have characteristics of both "pure" natural disasters such as tornados or hurricane storm surges and technological disasters such as a refinery explosion or mine collapse.

- Disasters affect a community's quality of life.

- Recovery after a wildfire depends greatly upon the social, economic, and infrastructural conditions of the community before the fire occurred.

A useful case study of the latter two impacts in the Southwest desert region was conducted by Carroll et al. (2005), who studied how three communities responded following the Rodeo-Chediski fire in northern Arizona. They suggested that the fire created both cohesion and conflict within the study communities. Cohesion was seen in how residents took action to rebuild their communities, e.g., managers of local businesses staying during evacuation to provide for the needs of firefighters, neighbors providing shelter and cleanup help for burned-out neighbors, and the emergence of locally based assistance groups. Several types of conflict emerged, rooted in blaming behaviors as well as the distribution of firefighting and disaster assistance resources, exacerbated by the fact that the affected communities included both Native American and nonreservation communities, with differing access to resources for reconstruction.

\section{MANAGEMENT IMPLICATIONS}

As frequency of wildfires in desert rangelands increases, some likely economic effects on ranches are that herd sizes will decrease, net ranch returns will decrease, and the probability of bankruptcy will increase. Maintaining ranches in livestock production can help buffer the effects of wildfire and invasion, as burned areas can be more prone to heavy cheatgrass invasion if they were not grazed prior to the fire (Davies et al. 2010). Cheatgrass invasion increases risk of future wildfires, but also provides an early-season forage that many ranchers have incorporated into their grazing regimes to reduce hay costs. Under current conditions, losing that forage source would likely cause further decline in ranch profitability unless other early-season forage options are found. Thus policy innovations may be needed to enhance survival of ranch enterprises in the wake of accelerated wildfire/invasion cycles. A potential survival strategy for ranchers is to develop supplemental income streams based on ecosystem services besides forage (e.g., recreation, renewable energy), but research is needed to estimate the effect of wildfire on other ecosystem services and their role in keeping a ranch in business or quickening its demise.

A significant confounding factor is the spread of low-density, exurban subdivisions in desert rangelands. Much of this exurban expansion has come via the conversion of working ranches to smaller holdings that serve as residential properties, creating a landscape that typically is fragmented (Mitchell et al. 2002) and may be more likely to be dominated by nonnative invasive species (Epanchin-Niell et al. 2010). The negative ecological implications of these changes have received considerable attention (Hansen et al. 2002; Maestas et al. 2003) as have the effects on working ranches (Rowe et al. 2001; Brunson and Huntsinger 2008). These landscapes have been a primary focus of wildfire mitigation and fuel hazard reduction activities, at least in terms of government policy. However, in practice less work has been done in the wildland-urban interface than expected or than the law directs (Schoennagel et al. 2009), partly because the negative impacts of fuels treatments are more obvious than the risks associated with wildfire. While various interest groups around the region have noted potential impacts of the wildfire/invasion cycle and developed educational materials that emphasize those impacts (e.g., the video "Buffelgrass Invasion" available from the Southern Arizona Buffelgrass Coordination Center 2010) there is need for scientific studies of actual impact to rural and exurban residents both economically and socially.

\section{LITERATURE CITED}

Aldrich, G. A., J. A. Tanaka, R. M. Adams, and J. C. Buckhouse. 2005. Economics of western juniper control in central Oregon. Rangeland Ecology \& Management 58:542-552.

Aslan, C. E., M. B. Hufford, R. S. Epanchin-Niell, J. D. Port, J. P. Sexton, and T. M. WARING. 2009. Practical challenges in private stewardship of rangeland ecosystems: yellow starthistle control in Sierra Nevadan foothills. Rangeland Ecology \& Management 62:28-37.

Bangsund, D. A., F. L. Leistritz, and J. A. Leitch. 1999. Assessing economic impacts of biological control of weeds: the case of leafy spurge in the northern Great Plains of the United States. Journal of Environmental Management 56:35-43.

Brunson, M. 2008. Gauging the acceptability of fuels management: a matter of trust. Rural Connections 2(3):2-4. Western Rural Development Center. Available at: http://wrdc.usu.edu/files/uploads/Newsletter/RC_apr08/RuralConnections_ apr08_web.pdf. Accessed 20 July 2011.

Brunson, M. W., AND J. Evans. 2005. Badly burned? Effects of an escaped prescribed burn on social acceptability of wildland fuels treatments. Journal of Forestry 103(April/May):134-138.

BRunson, M. W., AND L. Huntsinger. 2008. Ranching as a conservation strategy: can old ranchers save the New West? Rangeland Ecology \& Management 61:137-147.

Brunson, M. W., and B. A. Shindler. 2004. Geographic variation in social acceptability of wildland fuels management in the western U.S. Society and Natural Resources 17:661-678.

Carroll, M. S., P. J. Cohn, D. N. Seesholtz, and L. L. Higgins. 2005. Fire as a galvanizing and fragmenting influence on communities: the case of the Rodeo-Chediski fire. Society and Natural Resources 18:301-320.

Chambers, J. C., N. Devoe, and A. Evenden. 2009. Introduction. In: J. C. Chambers, N. Devoe, and A. Evenden [EDS.]. Collaborative management and research in the Great Basin-examining the issues and developing a framework for action. Fort Collins, CO, USA: USDA Forest Service, Rocky Mountain Research Station, Gen. Tech. Rep. RMRS-GTR-204. p. 1-7. 
Davies, K., J. Bates, and T. Svejcar. 2010. Moderate livestock grazing protects sagebrush plant communities from post-fire cheatgrass invasion. Corvallis, OR, USA: Oregon State University Beef Research Report, BEEF031.

Duncan, C. A., J. J. Jachetta, M. L. Brown, V. F. Carrithers, J. K. Clark, J. M. Ditomaso, R. K. Lym, K. C. McDaniel, M. J. Renz, and P. M. Rice. 2004. Assessing the economic, environmental, and societal losses from invasive plants on rangeland and wildlands. Weed Technology 18:1411-1416.

Eiswerth, M. E., T. D. Darden, W. S. Johnson, J. Agapoff, and T. R. Harris. 2005. Input-output modeling, outdoor recreation, and the economic impacts of weeds. Weed Science 53:130-137.

Epanchin-Niell, R. S., M. B. Hufford, C. E. Aslan, J. P. Sexton, J. D. Port, and T. M. WARING. 2010. Controlling invasive species in complex social landscapes. Frontiers in Ecology and the Environment 8:210-216.

Fenner, P. 2008. Effects of invasive plants on public land management of pinyonjuniper woodlands in Arizona. In: G. J. Gottfried, J. D. Shaw, and P. L. Ford [compilers]. Ecology, management, and restoration of piñon-juniper and ponderosa pine ecosystems: combined proceedings of the 2005 St. George, Utah and 2006 Albuquerque, New Mexico workshops. Fort Collins, CO, USA USDA Forest Service, Rocky Mountain Research Station, Proceedings RMRS-P-51. p. 113-120.

Hansen, A. J., R. Rasker, B. Maxwell, J. J. Rotella, J. D. Johnson, A. W. Parmenter, U. Langner, W. B. Cohen, R. L. Lawrence, and M. P. V. Kraska. 2002. Ecological causes and consequences of demographic change in the New West. BioScience 52:151-162.

HiRsCh, S. A., and J. A. Leitch. 1996. The impact of knapweed on Montana's economy. Fargo, ND, USA: North Dakota Agricultural Experiment Station, Agricultural Economics Report No. 355. 43 p.

Kumagal, Y., M. S. Carroll, and P. Cohn. 2004. Coping with interface wildfire as a human event: lessons from the disaster/hazards literature. Journal of Forestry 102(6):28-32.

Maestas, J. D., R. L. Knight, and W. C. GILgeRt. 2003. Biodiversity across a rural land-use gradient. Conservation Biology 17:1425-1434.

MAHeR, A. T. 2007. The economic impacts of sagebrush steppe wildfires on an eastern Oregon ranch [thesis]. Corvallis, OR, USA: Oregon State University. $171 \mathrm{p}$.

Mitchell, J. E., R. L. Knight, and R. J. Camp. 2002. Landscape attributes of subdivided ranches. Rangelands 24(1):3-9.

Morton, D. C., M. E. Roessing, A. E. Camp, and M. L. Tyrrell. 2003. Assessing the environmental, social, and economic impacts of wildfire. New Haven, CT, USA: Yale University, GISF Research Paper 001. 54 p.

Pimentel, D., L. Lach, R. Zuniga, and D. Morrison. 2000. Environmental and economic costs of nonindigenous species in the United States. BioScience $50: 53-65$.

Pimentel, D., R. Zuniga, and D. Morrison. 2005. Update on the environmental and economic costs associated with alien-invasive species in the United States. Ecological Economics 52:273-288.
Riggs, W., D. Breazeale, and G. Myer. 2001. Measuring the economic impacts from wildland fire. Journal of the American Society of Farm Managers and Rural Appraisers 64:39-42.

Rogstad, A. [ed.]. 2008. Southern Arizona buffelgrass strategic plan. Tucson, AZ, USA: Buffelgrass Working Group. 42 p.

Rowe, H. I., E. T. Bartlett JR., and L. E. Swanson JR. 2001. Ranching motivations in 2 Colorado counties. Journal of Range Management 54:314-321.

SATYAL, V. 2006. Economic and social impacts of restoration: a case study of the Great Basin region [dissertation]. Corvallis, OR, USA: Oregon State University. $133 p$.

Schoennagel, T., C. R. Nelson, D. M. Theobald, G. C. Carnath, and T. B. Chapman. 2009. Implementation of National Fire Plan treatments near the wildlandurban interface in the western United States. Proceedings of the National Academy of Sciences 106:10706-10711.

Shindler, B., R. Gordon, M. Brunson, and C. Olson. 2011. Public perceptions of sagebrush ecosystem management in the Great Basin. Rangeland Ecology \& Management 64:335-343.

Shindler, B., E. Toman, and S. McCaffrey. 2008. Wildland fire summit: a decade of social science research - summary of findings. Unpublished report prepared for the Wildland Fire Summit; August 2008; Portland, OR, USA. 8 p.

Southern Arizona Buffelgrass Coordination Center. 2007. Buffelgrass invasion in the Sonoran Desert: imminent risks and unavoidable mitigation. Available at: http://www.buffelgrass.org/sites/default/files/invasion.pdf. Accessed 20 July 2011.

Southern Arizona Buffelgrass Coordination Center. 2010. Buffelgrass invasion (film). Available at: http://www.buffelgrass.org. Accessed 20 July 2011.

TIDWELL, L. S. 2005. Information sources, willingness to volunteer, and attitudes toward invasive plants in the southwestern United States [thesis]. Logan, UT, USA: Utah State University. $131 \mathrm{p}$.

TIDWELL, L. S., AND M. W. BRUNSON. 2008. Volunteering to manage rangeland weeds: results of a citizen survey in the southwestern U.S. Rangelands 30(4):19-24.

Torell, L. A., N. R. Rimbey, J. A. Tanaka, and S. A. Balley. 2001. The lack of a profit motive for ranching: implications for policy analysis. In: L. A. Torell, E. T. Bartlett, and R. Larrañaga [EDS.]. Current issues in rangeland resource economics. Proceedings of a Symposium Sponsored by Western Coordinating Committee 55 at the Annual Meeting of the Society for Range Management; February 2001; Kona, HI, USA. Las Cruces, NM, USA: Western Regional Research Publication, New Mexico State University Agricultural Experiment Station Research Report 737. p. 47-58.

Torell, L. A., J. A. Tanaka, N. Rimbey, T. Darden, L. Van Tassell, and A. Harp. 2002. Ranch-level impacts of changing grazing policies on BLM land to protect the greater sage-grouse: evidence from Idaho, Nevada, and Oregon. Caldwell, ID, USA: Policy Analysis Center for Western Public Lands. PACWPL Policy Paper SG-01-02. 